\title{
Antiviral and immunoregulatory role against PCV2 in vivo of Chinese herbal medicinal ingredients
}

\author{
Haifeng Yang ${ }^{1}$, Xiaolan Chen ${ }^{1}$, Chunmao Jiang ${ }^{1}$, Kongwang $\mathrm{He}^{2,3}$, Yiyi $\mathrm{Hu}^{2,3}$ \\ ${ }^{1}$ Jiangsu Agri-animal Husbandry Vocational College, Taizhou, 225300 China \\ ${ }^{2}$ Institute of Veterinary Medicine, Jiangsu Academy of Agricultural Sciences, Nanjing, 210014 China \\ ${ }^{3}$ Jiangsu Co-innovation Center for Prevention and Control \\ of Important Animal Infectious Diseases and Zoonoses, Yangzhou, 225009 China \\ huyiyi6073@sina.com
}

Received: July 7, 2017 Accepted: December 4, 2017

\begin{abstract}
Introduction: The aim of the research was to investigate the antiviral and immunoregulatory effects of saikosaponin A, saikosaponin D, Panax notoginseng saponins, notoginsenoside R1, and anemoside B4 saponins commonly found in Chinese herbal medicines. Material and Methods: control mice were challenged intramuscularly (im) with $0.2 \mathrm{~mL}$ of porcine circovirus 2 (PCV2) solution containing $10^{7} \mathrm{TCID}_{50}$ of the virus $/ \mathrm{mL}$. Mice of high-, middle-, and low-dose saponin groups were initially challenged im with $0.2 \mathrm{~mL}$ of PCV2 solution and three days later treated intraperitoneally (ip) with one of five saponins at one of three doses (10, 5 , or $1 \mathrm{mg} / \mathrm{kg}$ b.w.). In the drug control group, mice were dosed ip with $10 \mathrm{mg} / \mathrm{kg} \mathrm{b.w.} \mathrm{of} \mathrm{a} \mathrm{given} \mathrm{saponin,} \mathrm{and} \mathrm{mice} \mathrm{in} \mathrm{a} \mathrm{blank}$ control group were administered the same volume of normal saline. Results: The results revealed that the saponins could reduce the incidence and severity of PCV2-induced immunopathological damage, e.g. body temperature elevation, weight loss, anaemia, and internal organ swelling. In addition, it was seen that the saponins could affect the immunoglobulin levels and protein absorption. Conclusion: The data suggested that the saponins might effectively regulate immune responses.
\end{abstract}

Keywords: porcine circovirus, saponins, antivirus properties, immune system.

\section{Introduction}

Porcine circovirus 2 (PCV2) is the smallest known animal virus, belonging to the genus Circovirus in the Circoviridae family (4). PCV2 was demonstrated to be a causative agent of porcine circovirus-associated disease (PCVAD), which includes porcine multi-systemic wasting syndrome (PMWS), porcine dermatitis and nephropathy syndrome (PDNS), porcine respiratory disease complex (PRDC), congenital tremor (CT), and reproductive failure $(6,12)$. Since its emergence in the early 1990s, PCVAD has continuously been a threat to the global swine industry, causing high economic losses $(14,28)$.

Vaccination is traditionally considered as the most effective method for preventing viral diseases $(13,16)$. However, the protection period given by the vaccine against disease is limited and the virus cannot be eradicated by vaccination (7). Furthermore, no effective vaccines are available for preventing multifactorial disease such as PCVAD (24). Therefore finding alternative effective measures to control the disease is an urgent need. Many Chinese herbal medicines can effectively suppress viral pathogens, in addition to eliminating fever and clearing toxins (26). They are also widely used to prevent or cure other non-viral infectious diseases, and show higher efficacy, lower toxicity, fewer side-effects, and lower residual levels than many commonly used drugs.

Saikosaponin A (SSA) and saikosaponin D (SSD) are major triterpenoid saponins derived from Bupleurum falcatum L. (Umbelliferae), commonly prescribed by Chinese and Japanese doctors for inflammatory and infectious diseases. These active components are reported to impart immunomodulatory, anti-inflammatory, anti-bacterial, anti-viral, and anti-cancer effects (15). Recently, it has been shown that SSD could exhibit an anti-proliferative effect in activated T-lymphocyte, in part via suppression of NF- $\kappa \mathrm{B}, \mathrm{NF}-\mathrm{AT}$, and AP-1 signalling (25). 
Panax notoginseng saponins (PNS) are the major active components of notoginseng. They consist of $>30$ different types of saponins; among these, ginsenosides $\mathrm{Rg} 1$ and Rb1 are found at high levels. PNS exhibit anticancer activity and have been shown to be effective against a variety of malignancies including colorectal, lung, gastric, skin, prostate, and liver cancers (2). Notoginsenoside R1 (SR1) is a component unique to notoginseng (27). It has been shown to be a promising compound for protecting the heart from septic shock and to impart anti-inflammatory effects (19). Pulsatilla koreana Nakai, with anemoside B4 (AB4) as its main pharmacological effective compound, is known to have numerous biological effects, including hypoglycaemic, anti-tumour, neuroprotective, and anti-angiogenic activity (20).

In the present study, the effects of five saponins, namely SSA, SSD, PNS, SR1, and AB4, were evaluated as antiviral and immunoregulatory agents. The effects of each were assessed via measures of impact on physiological and biochemical blood indices following exposure to PCV2. The aim of the studies was to provide a theoretical basis for further research on saponins and development of new drugs for use as antiviral and immunoregulatory agents.

\section{Material and Methods}

Reagents. Pure SSA, SSD, PNS, SR1, and AB4 (each at $20 \mathrm{mg} / \mathrm{vial}$; lot \#110777, \#110778, \#110745, $\# 110870$, and \#111766, respectively) were all purchased from the National Institute for Control of Pharmaceutical and Biological Products (Beijing, China). All ingredients were individually diluted to three concentrations $(1,5$, and $10 \mathrm{mg} / \mathrm{mL})$ with normal saline. The diluted solutions were then filtered through a $0.22-\mu \mathrm{m}$ membrane and stored at $4^{\circ} \mathrm{C}$.

Virus. The strain of PCV2 was isolated from a suspected PMWS case (11) at the Zoonotic Prevention and Control Laboratory at Jiangsu Academy of Agricultural Sciences and propagated on PK-15 cells. The titre of the virus, determined by IFA and PAMs, was $10^{7} \mathrm{TCID}_{50} / \mathrm{mL}$.

Animals. Balb/c mice (male, 18-22 g, six weeks of age), pre-tested negative for PCV2, were purchased from the Nanjing Biomedical Research Institute of Nanjing University (Nanjing, China). A total of 66 completely healthy mice were used. All mice were housed in pathogen-free facilities, maintained at $20^{\circ} \mathrm{C}$ with $50 \%$ relative humidity and 12 -h light:12-h dark cycle. All mice had ad libitum access to filtered tap water. All protocols used here were approved by the Department of Science and Technology of Jiangsu Province (license number SYXK (SU) 2015-0005). All efforts were made to minimise suffering.

Experimental protocol. The mice were randomly assigned to 22 equal groups. Over the course of the posttreatment period, each group was housed separately in different isolation rooms with individual ventilation. In the PCV2 control group, each mouse was challenged intramuscularly (im) with $0.2 \mathrm{~mL}$ of PCV2 solution containing $10^{7} \mathrm{TCID}_{50}$ of the virus $/ \mathrm{mL}$. In high-, middle-, and low-dose saponin groups, mice were initially challenged with $0.2 \mathrm{~mL}$ of the same PCV2 solution and three days later dosed intraperitoneally (ip) with one of five saponins at one of three doses $(10,5$, or $1 \mathrm{mg} / \mathrm{kg}$ b.w.). In the drug control group, mice were treated ip with 10 $\mathrm{mg} / \mathrm{kg} \mathrm{b}$.w. of a given saponin, while mice in the blank control group were administered the same volume of normal saline. The animal groups and experimental schedule used are shown in Table 1.

Determinations of physiological index. All animals were observed daily for clinical signs, and euthanised on day seven post-infection (dpi). Blood was collected from the retro-orbital plexus on the $7^{\text {th }} \mathrm{dpi}$ and serum was used for measures of $\operatorname{IgG}, \operatorname{IgM}$, albumin (ALB), globulin (GLO), total protein (TP), and alkaline phosphatase (ALP) using an AC-7020 automatic biochemical analyser (Hitachi, Japan). Blood collected into anti-coagulant coated tubes on the $7^{\text {th }}$ dpi was used for the analyses of haemoglobin (HGB) levels and white blood cell (WBC), red blood cell (RBC), platelet (PLT), and lymphocyte (LY) counts using a GTR-6000 automatic blood analyser (Glett, China).

Statistical analyses. All data were expressed as means \pm SD. A one-way analysis of variance (ANOVA) was used to determine the significance of differences between the PCV2 control group and the low-, middle-, and high-dose groups of each saponin, blank control group, and individual saponin control groups. All statistical analyses were performed using SPSS statistical software (v17.0, SPSS Inc., USA). When ANOVA results were significant, multiple comparisons of means were performed using a Dunnett's test analysis. Significant differences were assumed at $\mathrm{P}<0.05)$.

\section{Results}

TP and ALB levels. Compared with the PCV2 control group, TP levels were significantly increased in high- and middle-dose SSA, SSD, and PNS groups, and in the high-dose SR1 and AB4 groups (Table 2). This effect was (maximally) induced by $19.6 \%, 19.6 \%$, $21.6 \%, 20.8 \%, 25.5 \%, 17.3 \%, 23.2 \%$, and $20.4 \%$ with high and middle doses of SSA, SSD, and PNS, and high doses of SR1 and AB4, respectively. The ALB level in the PCV2 control mice was significantly decreased (by $18.5 \%$ ) to that in the blank control mice (Table 3). Compared with the PCV2 control group, ALB levels were significantly increased in the high- and middledose PNS groups $(27.6 \%$ and $19.5 \%)$, and in the highdose SR1 group (22.9\%).

IgG and IgM levels. Compared with the PCV2 control group, IgG levels were significantly increased in the high-dose SSA, SSD, and AB4 groups (Table 4). This effect was (maximally) induced by $17.9 \%, 19.1 \%$, and $17.1 \%$, with high-dose SSA, SSD, and AB4, 
respectively. No doses of the saponins had any impact on PCV2-induced IgM levels (Table 5).

WBC and RBC counts. As expected, WBC counts in PCV2 control mice decreased significantly (by $36.7 \%$ ) versus blank control mouse values (Table 6). Compared with PCV2 controls, WBC counts were significantly increased in high- and middle-dose SSA mice, and in high-dose SSD, PNS, and AB4 mice. WBC levels were maximally induced by $63.3 \%$, 46.2\%, $54.7 \%, 50.7 \%$, and $70.9 \%$, with high and middle doses of SSA, and high doses of SSD, PNS, and AB4, respectively. The RBC counts decreased by $18.4 \%$ in PCV2-only mice (Table 7). Compared with PCV2 control values, RBC counts increased significantly by $31.7 \%, 19.2 \%, 30.0 \%$, and $21.8 \%$ in high- and middledose PNS and SR1 mice, respectively.

Table 1. Animal groups and experimental schedule used

\begin{tabular}{|c|c|c|c|c|}
\hline \multirow{2}{*}{ Groups } & \multicolumn{2}{|c|}{$0 \mathrm{~h}$ by intramuscularly } & \multicolumn{2}{|c|}{$3 \mathrm{~h}$ intraperitoneally } \\
\hline & reagent & dose & reagent & dose \\
\hline PCV2 control & PCV2 & $10^{7} \mathrm{TCID}_{50}$ virus $/ \mathrm{mL}$ with $0.2 \mathrm{~mL}$ & - & - \\
\hline SSA high-dose & PCV2 & $10^{7} \mathrm{TCID}_{50}$ virus $/ \mathrm{mL}$ with $0.2 \mathrm{~mL}$ & SSA & $10 \mathrm{mg} / \mathrm{kg}$ \\
\hline SSA middle-dose & PCV2 & $10^{7} \mathrm{TCID}_{50}$ virus $/ \mathrm{mL}$ with $0.2 \mathrm{~mL}$ & SSA & $5 \mathrm{mg} / \mathrm{kg}$ \\
\hline SSA low-dose & $\mathrm{PCV} 2$ & $10^{7} \mathrm{TCID}_{50}$ virus $/ \mathrm{mL}$ with $0.2 \mathrm{~mL}$ & SSA & $1 \mathrm{mg} / \mathrm{kg}$ \\
\hline SSD high-dose & PCV2 & $10^{7} \mathrm{TCID}_{50}$ virus $/ \mathrm{mL}$ with $0.2 \mathrm{~mL}$ & SSD & $10 \mathrm{mg} / \mathrm{kg}$ \\
\hline SSD middle-dose & PCV2 & $10^{7} \mathrm{TCID}_{50}$ virus $/ \mathrm{mL}$ with $0.2 \mathrm{~mL}$ & SSD & $5 \mathrm{mg} / \mathrm{kg}$ \\
\hline SSD low -dose & PCV2 & $10^{7} \mathrm{TCID}_{50}$ virus $/ \mathrm{mL}$ with $0.2 \mathrm{~mL}$ & SSD & $1 \mathrm{mg} / \mathrm{kg}$ \\
\hline PNS high-dose & PCV2 & $10^{7} \mathrm{TCID}_{50}$ virus $/ \mathrm{mL}$ with $0.2 \mathrm{~mL}$ & PNS & $10 \mathrm{mg} / \mathrm{kg}$ \\
\hline PNS middle-dose & PCV2 & $10^{7} \mathrm{TCID}_{50}$ virus $/ \mathrm{mL}$ with $0.2 \mathrm{~mL}$ & PNS & $5 \mathrm{mg} / \mathrm{kg}$ \\
\hline PNS low -dose & PCV2 & $10^{7} \mathrm{TCID}_{50}$ virus $/ \mathrm{mL}$ with $0.2 \mathrm{~mL}$ & PNS & $1 \mathrm{mg} / \mathrm{kg}$ \\
\hline SR1 high-dose & PCV2 & $10^{7} \mathrm{TCID}_{50}$ virus $/ \mathrm{mL}$ with $0.2 \mathrm{~mL}$ & SR1 & $10 \mathrm{mg} / \mathrm{kg}$ \\
\hline SR1 middle-dose & PCV2 & $10^{7} \mathrm{TCID}_{50}$ virus $/ \mathrm{mL}$ with $0.2 \mathrm{~mL}$ & SR1 & $5 \mathrm{mg} / \mathrm{kg}$ \\
\hline SR1 low -dose & PCV2 & $10^{7} \mathrm{TCID}_{50}$ virus $/ \mathrm{mL}$ with $0.2 \mathrm{~mL}$ & SR1 & $1 \mathrm{mg} / \mathrm{kg}$ \\
\hline AB4 high-dose & PCV2 & $10^{7} \mathrm{TCID}_{50}$ virus $/ \mathrm{mL}$ with $0.2 \mathrm{~mL}$ & $\mathrm{AB} 4$ & $10 \mathrm{mg} / \mathrm{kg}$ \\
\hline AB4 middle-dose & PCV2 & $10^{7} \mathrm{TCID}_{50}$ virus $/ \mathrm{mL}$ with $0.2 \mathrm{~mL}$ & $\mathrm{AB} 4$ & $5 \mathrm{mg} / \mathrm{kg}$ \\
\hline AB4 low -dose & PCV2 & $10^{7} \mathrm{TCID}_{50}$ virus $/ \mathrm{mL}$ with $0.2 \mathrm{~mL}$ & $\mathrm{AB} 4$ & $1 \mathrm{mg} / \mathrm{kg}$ \\
\hline SSA control & - & - & SSA & $10 \mathrm{mg} / \mathrm{kg}$ \\
\hline SSD control & - & - & SSD & $10 \mathrm{mg} / \mathrm{kg}$ \\
\hline PNS control & - & - & PNS & $10 \mathrm{mg} / \mathrm{kg}$ \\
\hline SR1 control & - & - & SR1 & $10 \mathrm{mg} / \mathrm{kg}$ \\
\hline AB4 control & - & - & $\mathrm{AB} 4$ & $10 \mathrm{mg} / \mathrm{kg}$ \\
\hline Blank control & normal saline & the same volume & - & - \\
\hline
\end{tabular}

Table 2. TP contents ( $\mathrm{g} / \mathrm{L})$ in blood sera of each group

\begin{tabular}{|c|c|c|c|c|c|c|}
\hline \multirow[b]{2}{*}{ Groups } & \multicolumn{3}{|c|}{ Ingredient concentration } & \multirow{2}{*}{$\begin{array}{l}\text { Drug } \\
\text { control } \\
10 \mathrm{mg} / \mathrm{kg}\end{array}$} & \multirow{2}{*}{$\begin{array}{l}\text { PCV2 } \\
\text { control } \\
10^{5} \text { TCID50 }\end{array}$} & \multirow{2}{*}{$\begin{array}{l}\text { Blank } \\
\text { control } \\
-\end{array}$} \\
\hline & $10 \mathrm{mg} / \mathrm{kg}$ & $5 \mathrm{mg} / \mathrm{kg}$ & $1 \mathrm{mg} / \mathrm{kg}$ & & & \\
\hline SSA & $58.67 \pm 6.21^{*}$ & $58.67 \pm 7.44^{*}$ & $54.4 \pm 4.77$ & $56.0 \pm .8$ & & \\
\hline SSD & $59.67 \pm 1.31 * *$ & $59.3 \pm 4.18 * *$ & $54.43 \pm 4.8$ & $55.4 \pm 6.54$ & & \\
\hline PNS & $61.57 \pm 4.3^{* *}$ & $57.57 \pm 2.35^{*}$ & $53.2 \pm 5.02$ & $54.87 \pm 3.0$ & $28.4 \pm 1.45$ & $52.07 \pm 1.91$ \\
\hline SR1 & $60.43 \pm 8.52 * *$ & $55.8 \pm 1.55$ & $54.4 \pm 5.0$ & $54.13 \pm 3.89$ & & \\
\hline $\mathrm{AB} 4$ & $59.07 \pm 3.1 *$ & $54.33 \pm 5.19$ & $51.0 \pm 0.79$ & $51.93 \pm 2.61$ & & \\
\hline
\end{tabular}

Data shown are mean $( \pm \mathrm{SD}) \mathrm{g} / \mathrm{L}$

Value significantly different from $\mathrm{PCV} 2$ control group at $* \mathrm{P}<0.05$ or $* * \mathrm{P}<0.01$

Table 3. ALB contents $(\mathrm{g} / \mathrm{L})$ in blood sera of each group

\begin{tabular}{|c|c|c|c|c|c|c|}
\hline \multirow[b]{2}{*}{ Groups } & \multicolumn{3}{|c|}{ Ingredient concentration } & \multirow{2}{*}{$\begin{array}{l}\text { Drug } \\
\text { control } \\
10 \mathrm{mg} / \mathrm{kg}\end{array}$} & \multirow{2}{*}{$\begin{array}{l}\text { PCV2 } \\
\text { control } \\
10^{5} \text { TCID50 }\end{array}$} & \multirow{2}{*}{$\begin{array}{l}\text { Blank } \\
\text { control } \\
-\end{array}$} \\
\hline & $10 \mathrm{mg} / \mathrm{kg}$ & $5 \mathrm{mg} / \mathrm{kg}$ & $1 \mathrm{mg} / \mathrm{kg}$ & & & \\
\hline SSA & $31.97 \pm 4.06$ & $32.47 \pm 4.99$ & $29.8 \pm 2.88$ & $35.37 \pm 2.22$ & & \\
\hline SSD & $32.57 \pm 2.15$ & $32.67 \pm 3.12$ & $30.6 \pm 3.29$ & $33.4 \pm 4.16$ & & \\
\hline PNS & $36.23 \pm 2.4 * *$ & $33.93 \pm 1.46^{*}$ & $31.27 \pm 2.18$ & $36.03 \pm 2.3$ & $4.92 \pm 0.35$ & $34.83 \pm 1.58^{* *}$ \\
\hline SR1 & $34.90 \pm 3.73 * *$ & $32.60 \pm 3.03$ & $31.10 \pm 3.04$ & $35.13 \pm 1.25$ & & \\
\hline $\mathrm{AB} 4$ & $33.00 \pm 2.55$ & $30.83 \pm 1.7$ & $28.77 \pm 2.59$ & $33.20 \pm 1.78$ & & \\
\hline
\end{tabular}

Data shown are means $( \pm \mathrm{SD}) \mathrm{g} / \mathrm{L}$

Value significantly different from $\mathrm{PCV} 2$ control group at $* \mathrm{P}<0.05$ or $* * \mathrm{P}<0.01$

Table 4. IgG contents $(\mathrm{g} / \mathrm{L})$ in blood sera of each group

\begin{tabular}{|c|c|c|c|c|c|c|}
\hline \multirow[b]{2}{*}{ Groups } & \multicolumn{3}{|c|}{ Ingredient concentration } & \multirow{2}{*}{$\begin{array}{l}\text { Drug } \\
\text { control } \\
10 \mathrm{mg} / \mathrm{kg} \\
\end{array}$} & \multirow{2}{*}{$\begin{array}{l}\text { PCV2 } \\
\text { control } \\
10^{5} \text { TCID50 }\end{array}$} & \multirow{2}{*}{$\begin{array}{c}\text { Blank } \\
\text { control } \\
-\end{array}$} \\
\hline & $10 \mathrm{mg} / \mathrm{kg}$ & $5 \mathrm{mg} / \mathrm{kg}$ & $1 \mathrm{mg} / \mathrm{kg}$ & & & \\
\hline SSA & $5.8 \pm 0.23 *$ & $5.35 \pm 0.73$ & $5.02 \pm 0.28$ & $4.81 \pm 0.47$ & & \\
\hline SSD & $5.86 \pm 0.28 *$ & $5.6 \pm 0.57$ & $5.23 \pm 0.29$ & $4.96 \pm 0.27$ & & \\
\hline PNS & $5.53 \pm 0.72$ & $5.12 \pm 0.48$ & $4.70 \pm 0.57$ & $4.54 \pm 0.48$ & $4.92 \pm 0.35$ & $4.18 \pm 0.38$ \\
\hline SR1 & $5.34 \pm 0.78$ & $5.23 \pm 0.61$ & $4.57 \pm 0.29$ & $4.68 \pm 0.41$ & & \\
\hline $\mathrm{AB} 4$ & $5.76 \pm 0.4^{*}$ & $5.39 \pm 0.67$ & $4.88 \pm 0.69$ & $4.64 \pm 0.51$ & & \\
\hline
\end{tabular}

Data shown are mean $( \pm \mathrm{SD}) \mathrm{g} / \mathrm{L}$

Value significantly different from $\mathrm{PCV} 2$ control group at $* \mathrm{P}<0.05$ 
Table 5. IgM contents $(\mathrm{g} / \mathrm{L})$ in blood sera of each group

\begin{tabular}{|c|c|c|c|c|c|c|}
\hline \multirow[b]{2}{*}{ Groups } & \multicolumn{3}{|c|}{ Ingredient concentration } & \multirow{2}{*}{$\begin{array}{l}\begin{array}{l}\text { Drug } \\
\text { control } \\
10 \mathrm{mg} / \mathrm{kg}\end{array} \\
\end{array}$} & \multirow{2}{*}{$\begin{array}{l}\text { PCV2 } \\
\text { control } \\
10^{5} \text { TCID50 }\end{array}$} & \multirow{2}{*}{$\begin{array}{l}\text { Blank } \\
\text { control } \\
-\end{array}$} \\
\hline & $10 \mathrm{mg} / \mathrm{kg}$ & $5 \mathrm{mg} / \mathrm{kg}$ & $1 \mathrm{mg} / \mathrm{kg}$ & & & \\
\hline SSA & $0.93 \pm 0.13$ & $0.84 \pm 0.24$ & $0.79 \pm 0.21$ & $0.87 \pm 0.1$ & & \\
\hline SSD & $1.0 \pm 0.18$ & $0.85 \pm 0.14$ & $0.76 \pm 0.14$ & $0.9 \pm 0.14$ & & \\
\hline PNS & $0.88 \pm 0.18$ & $0.82 \pm 0.11$ & $0.77 \pm 0.13$ & $0.75 \pm 0.1$ & $0.82 \pm 0.09$ & $0.67 \pm 0.11$ \\
\hline SR1 & $0.87 \pm 0.13$ & $0.8 \pm 0.19$ & $0.83 \pm 0.18$ & $0.85 \pm 0.15$ & & \\
\hline $\mathrm{AB} 4$ & $0.96 \pm 0.11$ & $0.91 \pm 0.25$ & $0.85 \pm 0.05$ & $0.83 \pm 0.12$ & & \\
\hline
\end{tabular}

Data shown are mean $( \pm \mathrm{SD}) \mathrm{g} / \mathrm{L}$

Value significantly different from PCV2 control group at $* \mathrm{P}<0.05$

Table 6. WBC contents $\left(10^{9} / \mathrm{L}\right)$ in anticoagulated blood of each group

\begin{tabular}{|c|c|c|c|c|c|c|}
\hline \multirow[b]{2}{*}{ Groups } & \multicolumn{3}{|c|}{ Ingredient concentration } & \multirow{2}{*}{$\begin{array}{l}\text { Drug } \\
\text { control } \\
10 \mathrm{mg} / \mathrm{kg} \\
\end{array}$} & \multirow{2}{*}{$\begin{array}{l}\text { PCV2 } \\
\text { control } \\
10^{5} \text { TCID50 }\end{array}$} & \multirow{2}{*}{$\begin{array}{l}\text { Blank } \\
\text { control } \\
-\end{array}$} \\
\hline & $10 \mathrm{mg} / \mathrm{kg}$ & $5 \mathrm{mg} / \mathrm{kg}$ & $1 \mathrm{mg} / \mathrm{kg}$ & & & \\
\hline SSA & $18.13 \pm 3.88^{* *}$ & $16.23 \pm 2.3^{*}$ & $13.60 \pm 1.35$ & $18.77 \pm 2.35$ & & \\
\hline SSD & $17.17 \pm 1.4^{*}$ & $15.03 \pm 1.42$ & $15.23 \pm 2.35$ & $17.50 \pm 1.57$ & & \\
\hline PNS & $16.73 \pm 4.7 *$ & $14.97 \pm 3.1$ & $13.33 \pm 4.49$ & $16.93 \pm 4.62$ & $11.10 \pm 1.93$ & $17.53 \pm 1.7 * *$ \\
\hline SR1 & $15.27 \pm 2.87$ & $14.97 \pm 3.26$ & $14.40 \pm 2.35$ & $16.90 \pm 3.12$ & & \\
\hline $\mathrm{AB} 4$ & $18.97 \pm 1.67 * *$ & $15.30 \pm 2.46$ & $15.20 \pm 2.74$ & $19.57 \pm 2.7$ & & \\
\hline
\end{tabular}

Data shown are mean $( \pm \mathrm{SD}) 10^{9} / \mathrm{L}$

Value significantly different from PCV2 control group at $* \mathrm{P}<0.05$ or $* * \mathrm{P}<0.01$

Table 7. RBC contents $\left(10^{12} / \mathrm{L}\right)$ in anticoagulated blood of each group

\begin{tabular}{|c|c|c|c|c|c|c|}
\hline \multirow[b]{2}{*}{ Groups } & \multicolumn{3}{|c|}{ Ingredient concentration } & \multirow{2}{*}{$\begin{array}{l}\text { Drug } \\
\text { control } \\
10 \mathrm{mg} / \mathrm{kg}\end{array}$} & \multirow{2}{*}{$\begin{array}{l}\text { PCV2 } \\
\text { control } \\
10^{5} \text { TCID50 }\end{array}$} & \multirow{2}{*}{$\begin{array}{l}\text { Blank } \\
\text { control } \\
-\end{array}$} \\
\hline & $10 \mathrm{mg} / \mathrm{kg}$ & $5 \mathrm{mg} / \mathrm{kg}$ & $1 \mathrm{mg} / \mathrm{kg}$ & & & \\
\hline SSA & $5.68 \pm 0.64$ & $5.79 \pm 0.19$ & $5.67 \pm 0.55$ & $5.71 \pm 0.32$ & & \\
\hline SSD & $5.69 \pm 0.48$ & $5.67 \pm 0.49$ & $5.71 \pm 0.56$ & $6.14 \pm 0.70$ & & \\
\hline PNS & $6.53 \pm 0.58 * *$ & $5.91 \pm 0.68 *$ & $5.70 \pm 0.63$ & $6.61 \pm 0.54$ & $4.96 \pm 0.49$ & $6.08 \pm 0.64^{*}$ \\
\hline SR1 & $6.45 \pm 0.72 * *$ & $6.05 \pm 0.63 *$ & $5.65 \pm 0.92$ & $6.04 \pm 0.37$ & & \\
\hline $\mathrm{AB} 4$ & $5.81 \pm 0.55$ & $5.75 \pm 0.24$ & $5.46 \pm 0.76$ & $5.69 \pm 0.29$ & & \\
\hline
\end{tabular}

Data shown are mean $( \pm \mathrm{SD}) 10^{12} / \mathrm{L}$

Value significantly different from $\mathrm{PCV} 2$ control group at $* \mathrm{P}<0.05$ or $* * \mathrm{P}<0.01$

Table 8. HGB contents $(\mathrm{g} / \mathrm{L})$ in anticoagulated blood of each group

\begin{tabular}{|c|c|c|c|c|c|c|}
\hline \multirow[b]{2}{*}{ Groups } & \multicolumn{3}{|c|}{ Ingredient concentration } & \multirow{2}{*}{$\begin{array}{l}\begin{array}{l}\text { Drug } \\
\text { control } \\
10 \mathrm{mg} / \mathrm{kg}\end{array} \\
\end{array}$} & \multirow{2}{*}{$\begin{array}{l}\text { PCV2 } \\
\text { control } \\
10^{5} \text { TCID50 }\end{array}$} & \multirow{2}{*}{$\begin{array}{l}\text { Blank } \\
\text { control } \\
-\end{array}$} \\
\hline & $10 \mathrm{mg} / \mathrm{kg}$ & $5 \mathrm{mg} / \mathrm{kg}$ & $1 \mathrm{mg} / \mathrm{kg}$ & & & \\
\hline SSA & $120.3 \pm 13.32 * *$ & $108.3 \pm 7.77$ & $109.3 \pm 9.87$ & $115.7 \pm 10.26$ & & \\
\hline PNS & $125.3 \pm 8.02 * *$ & $118.7 \pm 6.51^{*}$ & $109.0 \pm 8.54$ & $121.0 \pm 12.53$ & $97.7 \pm 6.11$ & $123.7 \pm 11.93 * *$ \\
\hline SR1 & $126.7 \pm 12.66^{* *}$ & $122.0 \pm 8.54 * *$ & $112.7 \pm 9.5$ & $127.3 \pm 10.41$ & & \\
\hline $\mathrm{AB} 4$ & $113.0 \pm 9.64$ & $105.3 \pm .64$ & $97.0 \pm 8.19$ & $113.0 \pm 11.14$ & & \\
\hline
\end{tabular}

Data shown are mean $( \pm \mathrm{SD}) \mathrm{g} / \mathrm{L}$

Value significantly different from $\mathrm{PCV} 2$ control group at $* \mathrm{P}<0.05$ or $* * \mathrm{P}<0.01$

Table 9. PLT contents $\left(10^{9} / \mathrm{L}\right)$ in anticoagulated blood of each group

\begin{tabular}{|c|c|c|c|c|c|c|}
\hline \multirow[b]{2}{*}{ Groups } & \multicolumn{3}{|c|}{ Ingredient concentration } & \multirow{2}{*}{$\begin{array}{l}\text { Drug } \\
\text { control } \\
10 \mathrm{mg} / \mathrm{kg} \\
\end{array}$} & \multirow{2}{*}{$\begin{array}{l}\text { PCV2 } \\
\text { control } \\
10^{5} \text { TCID50 }\end{array}$} & \multirow{2}{*}{$\begin{array}{l}\text { Blank } \\
\text { control } \\
-\end{array}$} \\
\hline & $10 \mathrm{mg} / \mathrm{kg}$ & $5 \mathrm{mg} / \mathrm{kg}$ & $1 \mathrm{mg} / \mathrm{kg}$ & & & \\
\hline SSA & $246.7 \pm 35.64$ & $249.7 \pm 42.53$ & $225.7 \pm 43.84$ & $220.0 \pm 41.22$ & & \\
\hline SSD & $274.3 \pm 41.5$ & $267.0 \pm 34.4$ & $263.0 \pm 36.59$ & $261.3 \pm 34.12$ & & \\
\hline PNS & $249.0 \pm 24.98$ & $265.3 \pm 16.65$ & $267.3 \pm 46.92$ & $249.7 \pm 47.44$ & $237.3 \pm 46.18$ & $250.3 \pm 46.05$ \\
\hline SR1 & $264.0 \pm 49.73$ & $252.0 \pm 18.03$ & $261.7 \pm 34.78$ & $281.7 \pm 37.5$ & & \\
\hline $\mathrm{AB} 4$ & $257.7 \pm 41.07$ & $237.7 \pm 29.37$ & $248.3 \pm 45.49$ & $270.3 \pm 33.01$ & & \\
\hline
\end{tabular}

Data shown are mean $( \pm \mathrm{SD}) 10^{9} / \mathrm{L}$

Value significantly different from PCV2 control group at $* \mathrm{P}<0.05$

HGB and PLT levels. The HGB levels decreased by $21.0 \%$ (relative to control) in the PCV2 control group mice (Table 8). Compared with PCV2 control values, HGB levels were significantly increased, rising by $28.2 \%, 21.5 \%, 29.7 \%, 24.9 \%$, and $23.1 \%$, in high- and middle-dose PNS and SR1 and high-dose SSA mice respectively. No doses of the saponins had any impact on PCV2-induced PLT levels (Table 9).

\section{Discussion}

Chinese herbal medicine can regulate the balance of cellular functions and improve the physiological conditions of the organism in many ways. Accordingly, many studies have recently focused on the use of Chinese herbal medicines to treat or prevent PCV2induced health disorders (23). Existing data show that 
PCV2 induces pathological effects which can cause an imbalance in a variety of protein levels and cell numbers $(5,17,18)$. The experiments here suggested that each of the five test saponins could reduce the incidence and severity of some aspects of virus-associated pathologies, like the protein absorption barrier, immune suppression, and anaemia in mice. The present results also suggest that in general, saponins might be used as part of a therapeutic immunoenhancement regimen.

The serum TP value, to a certain extent, represents the level of proteins in the diet and degree of protein digestion and absorption (8). In the present study, it was seen that TP levels were significantly promoted by all tested saponins, with SSD having the greatest effect. Albumin, which can be used to repair tissue and provide energy, was shown to be significantly induced by PNS and SR1 in a dose-related manner. The TP consists of albumin and globulin. Panax pseudo-ginseng saponins could significantly increase the level of albumin to repair liver damage, while bupleuri saponins could significantly improve the level of globulin to enhance immune function. They all increase the total protein content, which promoted the absorption and utilisation of nutrients, but there is no improvement in the proportion of albumin to globulin.

IgG shows the highest concentration in the serum of animals. It can exhibit antibacterial, antiviral, and antitoxin immunological activity (10). At the same time, IgG was the main antibody in the serological diagnosis and monitoring of the vaccine (1). We found that the level of IgG was significantly increased by SSD. This could represent a mechanism by which saponins could sometimes be used in the treatment of immune disorders. It is known that $\operatorname{IgG}$ and $\operatorname{IgM}$ are important immunoglobulins in humoral responses. SSA and SSD could improve the neutralisation effect of the immunoglobulins against the virus $(3,29)$. Because of the low content of IgA in serum, we did not detect the correlation value.

During infection-related stress, there is a typical decrease in the number of WBC and RBC. The present study showed that the WBC count was significantly increased (relative to levels in infected control hosts) by all the saponins except SR1. Many studies have revealed that neutrophil number down-regulation is one of the basic characteristics of PCV2 infection. The current study confirmed this phenomenon. It is clear that downregulation of WBC may cause immunosuppression. The effects of WBC are diverse but mainly comprise antiinflammatory activity, mediating the negative feedback of $\mathrm{T}_{\mathrm{H}} 1$ and $\mathrm{T}_{\mathrm{H}} 2$ immune responses. Previous findings have confirmed that RBC also has an immunoregulatory function. The ability of PNS and SR1 to increase RBC number after PCV2 exposure was much higher than that noted in their respective control groups.

Saponins possess the ability to clear toxic materials, alleviate pain, and improve blood circulation $(21,22)$. In the present study, the amount of HGB was dramatically down-regulated in response to PCV2. Such findings are in line with those of other studies. During a PCV2 infection, down-regulated HGB production may result in small cell anaemia. In the current study there was upregulation of $\mathrm{HGB}$ by $\mathrm{PNS}$ or SR1 after direct stimulation with PCV2. Ongoing studies in our laboratories will need to ascertain the modulated pathways of saponins tested in immune and pathological physiology.

The five saponins may exert some therapeutic effects on the immune and circulatory systems and counter immunomodulatory effects and related syndromes induced by viral infection, at least in part by modulating the content of immunoglobulin and HGB. In addition, it was seen that PCV2 could affect the temperature and weight of tested mice. The previous study in vitro showed that production of IL-4, IL-10, IL-2, and IFN was also specifically affected when target cells had already been stimulated with PCV2 (9). These findings warrant saponins being further explored for their antiviral activity in clinical settings. Future studies will elaborate the specific way each of the tested saponins acts against the virus.

Conflict of Interests Statement: The authors declare that there is no conflict of interests regarding the publication of this article.

Financial Disclosure Statement: This work was supported by National Natural Science Foundation of China (31502112), Special Fund for Public Welfare Industry of Chinese Ministry of Agriculture (201403051), Jiangsu province Natural Sciences Foundation (BK20161368), Jiangsu province three new projects of agriculture (SXGC[2016]296), Taizhou science and technology support program agricultural project (TN201711), and Jiangsu Agri-animal Husbandry Vocational College research project (NSF201704).

Animal Rights Statement: All experimental protocols used here were approved by the Department of Science and Technology of Jiangsu Province.

Acknowledgements: The authors greatly appreciate the help they received from all of our colleagues and collaborators during the experiments.

\section{References}

1. Boi C., Dimartino S., Hofer S., Horak J., Williams S., Sarti G.C., Lindner W.: Influence of different spacer arms on Mimetic Ligand $\mathrm{A} 2 \mathrm{P}$ and B14 membranes for human $\mathrm{IgG}$ purification. J Chromatogr B Analyt Technol Biomed Life Sci 2011, 879, 1633-1640.

2. Chen H., Yin J., Deng Y., Yang M., Xu L., Teng F., Li D., Cheng Y., Liu S., Wang D., Zhang T., Wu W., Liu X., Guan S., Jiang B., Guo D.: The protective effects of ginsenoside Rg1 against hypertension target-organ damage in spontaneously hypertensive rats. BMC Complement Altern Med 2012, 12, 53-62. 
3. Chen M.F., Huang C.C., Liu P.S., Chen C.H., Shiu L.Y. Saikosaponin a and saikosaponin $\mathrm{d}$ inhibit proliferation and migratory activity of rat HSC-T6 cells. J Med Food 2013, 16, 793-800

4. Chen X., Ren F., Hesketh J., Shi X., Li J., Gan F., Huang K.: Reactive oxygen species regulate the replication of porcine circovirus type 2 via NF-kappaB pathway. Virology 2012, 426, 66-72.

5. Darwich L., Balasch M., Plana-Duran J., Segales J., Domingo M., Mateu E.: Cytokine profiles of peripheral blood mononuclear cells from pigs with postweaning multisystemic wasting syndrome in response to mitogen, superantigen or recall viral antigens. J Gen Virol 2003, 84, 3453-3457.

6. Duan D., Zhang S., Li X., Guo H., Chen M., Zhang Y., Han J., Lv Y.: Activation of the TLR/MyD88/NF-kappaB signal pathway contributes to changes in IL-4 and IL-12 production in piglet lymphocytes infected with porcine circovirus type 2 in vitro. PLoS One 2014, 9, e97653.

7. Feng H., Blanco G., Segales J., Sibila M.: Can porcine circovirus type 2 (PCV2) infection be eradicated by mass vaccination? Vet Microbiol 2014, 172, 92-99.

8. Gutierrez A.M., Ceron J.J., Fuentes P., Montes A., MartinezSubiela S.: Longitudinal analysis of acute-phase proteins in saliva in pig farms with different health status. Animal 2012, 6, 321-326.

9. $\mathrm{Hu}$ Y., He K., Wang X.: Role of Chinese herbal medicinal ingredients in secretion of cytokines by PCV2-induced endothelial cells. J Immunotoxicol 2016, 13, 141-147.

10. Jelezarova E., Lutz H.U.: IgG naturally occurring antibodies stabilize and promote the generation of the alternative complement pathway C3 convertase. Mol Immunol 2005, 42, 1393-1403.

11. Li B., Ma J., Liu Y., Wen L., Yu Z., Ni Y., Zhang X., Zhou J., Guo R., Wang X., Feng Z., Hu Y., Lv L., He K.: Complete genome sequence of a highly prevalent porcine circovirus 2 isolated from piglet stool samples in China. J Virol 2012, 86, 4716.

12. Lv Y., Zhang X., Sun Y., Zhang S.: Activation of NF-kappaB contributes to production of pig-major acute protein and serum amyloid A in pigs experimentally infected with porcine circovirus type 2. Res Vet Sci 2013, 95, 1235-1240.

13. Lyoo K.S., Joo H.S., Davies P.R., Han J.H.: Comparison of porcine circovirus type 2 (PCV2) infection in light and heavy pigs of market age on farms with routine PCV2 vaccination. Can J Vet Res 2012, 76, 221-223.

14. Madson D.M., Opriessnig T.: Effect of porcine circovirus type 2 (PCV2) infection on reproduction: disease, vertical transmission, diagnostics and vaccination. Anim Health Res Rev 2011, 12, 47-65.

15. Na-Bangchang K., Karbwang J.: Traditional herbal medicine for the control of tropical diseases. Trop Med Health 2014, 42, 3-13.

16. Pejsak Z., Kusior G., Pomorska-Mol M., Podgorska K.: Influence of long-term vaccination of a breeding herd of pigs against PCV2 on reproductive parameters. Pol J Vet Sci 2012, 15, 37-42.

17. Pejsak Z., Markowska-Daniel I., Pomorska-Mol M., Porowski M., Kolacz R.: Ear necrosis reduction in pigs after vaccination against PCV2. Res Vet Sci 2011, 91, 125-128.
18. Sipos W., Duvigneau J.C., Willheim M., Schilcher F., Hartl R.T., Hofbauer G., Exel B., Pietschmann P., Schmoll F.: Systemic cytokine profile in feeder pigs suffering from natural postweaning multisystemic wasting syndrome (PMWS) as determined by semiquantitative RT-PCR and flow cytometric intracellular cytokine detection. Vet Immunol Immunopathol 2004, 99, 63-71.

19. Su P., Du S., Li H., Li Z., Xin W., Zhang W.: Notoginsenoside R1 inhibits oxidized low-density lipoprotein induced inflammatory cytokines production in human endothelial EA.hy926 cells. Eur J Pharmacol 2016, 770, 9-15.

20. Sun B., Xiao J., Sun X.B., Wu Y.: Notoginsenoside R1 attenuates cardiac dysfunction in endotoxemic mice: an insight into oestrogen receptor activation and $\mathrm{PI} 3 \mathrm{~K} /$ Akt signalling. $\mathrm{Br} \mathrm{J}$ Pharmacol 2013, 168, 1758-1770.

21. Sun H., Chen L., Wang J., Wang K., Zhou J.: Structure-function relationship of the saponins from the roots of Platycodon grandiflorum for hemolytic and adjuvant activity. Int Immunopharmacol 2011, 11, 2047-2056.

22. Sun H., He S., Shi M.: Adjuvant-active fraction from Albizia julibrissin saponins improves immune responses by inducing cytokine and chemokine at the site of injection. Int Immunopharmacol 2014, 22, 346-355.

23. Sun N., Sun P., Lv H., Sun Y., Guo J., Wang Z., Luo T., Wang S., Li H.: Matrine displayed antiviral activity in porcine alveolar macrophages co-infected by porcine reproductive and respiratory syndrome virus and porcine circovirus type 2. Sci Rep 2016, 6, 24401-24413.

24. Trible B.R., Kerrigan M., Crossland N., Potter M., Faaberg K., Hesse R., Rowland R.R.: Antibody recognition of porcine circovirus type 2 capsid protein epitopes after vaccination, infection, and disease. Clin Vaccine Immunol 2011, 18, 749-757.

25. Tundis R., Bonesi M., Deguin B., Loizzo M.R., Menichini F., Conforti F., Tillequin F., Menichini F.: Cytotoxic activity and inhibitory effect on nitric oxide production of triterpene saponins from the roots of Physospermum verticillatum (Waldst \& Kit) (Apiaceae). Bioorg Med Chem 2009, 17, 4542-4547.

26. Wang X., Liu Z.: Prevention and treatment of viral respiratory infections by traditional Chinese herbs. Chin Med J 2014, 127, 1344-1350.

27. Wong V.K., Zhou H., Cheung S.S., Li T., Liu L.: Mechanistic study of saikosaponin-d (Ssd) on suppression of murine T lymphocyte activation. J Cell Biochem 2009, 107, 303-315.

28. Zhai S.L., Chen S.N., Xu Z.H., Tang M.H., Wang F.G., Li X.J., Sun B.B., Deng S.F., Hu J., Lv D.H., Wen X.H., Yuan J., Luo M.L., Wei W.K.: Porcine circovirus type 2 in China: an update on and insights to its prevalence and control. Virol J 2014, 11, 88100.

29. Zhu S., Ling F., Zhang Q., Liu G., Tu X., Jiang C., Wang G.: Anthelmintic activity of saikosaponins a and $\mathrm{d}$ from radix bupleuri against Dactylogyrus spp. infecting goldfish. Dis Aquat Organ 2014, 111, 177-182. 